\title{
The effects of organic selenium on performance and oxidative level in rainbow trout (Oncorhynchus mykiss, Walbaum, 1792) fed a high-fat diet
}

\author{
A. Keramat Amirkolaie ${ }^{1,3}$, J. Karimzadeh ${ }^{2}$ and A. Abedian Kenari ${ }^{2}$ \\ ${ }^{1}$ Sari Agricultural Sciences and Natural Resources University (SANRU), Faculty of Animal Sciences and Fisheries, \\ Department of Fisheries, P.O.Box: 578, Sari, Iran \\ ${ }^{2}$ Tarbiat Modares University, Department of Fisheries, P.O.Box: 46414-356, Noor, Iran
}

KEY WORDS: organic selenium, dietary fat, oxidation, glutathione peroxidase, rainbow trout

Received: 16 April 2013

Revised: 25 December 2013

Accepted: 4 March 2014

${ }^{3}$ Corresponding author:

e-mail: amirkola@yahoo.com

\begin{abstract}
The main objective of this study was to determine the impact of dietary fat on the organic selenium requirement of rainbow trout. There were two variables in this study. The first was organic selenium that was supplemented at $0.1,0.15$ and $0.2 \mathrm{mg} \cdot \mathrm{kg}^{-1}$. The second variable was the fat inclusion level as low-fat (15\%) and high-fat (30\%) diets. This led to formulation of six experimental diets according to a $3 \times 2$ factorial design. Juvenile rainbow trout with an initial weight of $6.99 \pm 0.9 \mathrm{~g}$ were assigned to 18 tanks with 25 fish each, with three replicates for each diet. The results showed that the tissue oxidation rate increased with increased dietary fat content. The initial and final fish stocking densities were 0.58 and $2.08 \mathrm{~kg} \cdot \mathrm{m}^{-3}$, respectively. Addition of dietary selenium increased glutathione peroxidase activity. Final weight and specific growth rate were not influenced by the fat level of the diets. On the high-fat diet, selenium improved the feed conversion ratio by depression of the oxidation rate. The dietary selenium requirement depended on the dietary fat content and $0.15 \mathrm{mg} \cdot \mathrm{kg}^{-1}$ was found to be necessary for the high-fat diet. A reduction in oxidation level by inclusion of selenium into the diets was observed and was associated with the higher activity of glutathione peroxidase.
\end{abstract}

\section{Introduction}

Increasing the dietary energy level through addition of fat has improved fish growth performance in a number of species (Hung et al., 1997; Yamamoto et al., 2002; Morais et al., 2005). A high-fat diet can also meet the energy requirement for a shorter grow out period when the fish body deposits more fat (Dumas et al., 2007). This condition has led to an increase in fat and/or energy content of trout diets in recent years (Sargent et al., 2002). Not only fish farms benefit, also less nitrogen is released into the environment (Cho and Bureau, 2001).The maximum fat addition for trout diets was $10 \%$ in the 1980 s but it reached $24 \%$ in the 2000s (Bureau and Hua, 2010). An even higher concentration of dietary fat (30\%) was reported by Chaiyapechara et al. (2003). A fat level of $40 \%$ has also been reported for manufacturing salmon diets (Turchini et al., 2009).

An increase in dietary fat content is associated with increasing the whole body fat content in rainbow trout (Jobling et al., 1998; Steffens et al., 1999; 
Rasmussen, 2001; Ruohonen et al., 2001). This increase can elevate the oxidation level, leading to oxidative stress that may cause disease (Sakai et al., 1998) and reduce the quality of the fillet (Chaiyapechara et al., 2003). Selenium (Se) is an essential micronutrient for vertebrates, including fish (Wiseman et al., 2011). This element may play a significant role in antioxidant defense in fish with physiological non-enzymatic antioxidant properties (Mruk et al., 2002; Nogueira et al., 2003; Cheung et al., 2004). $\mathrm{Se}$, as a component of the enzyme, glutathione peroxidase (GSH-px) (Rotruck et al., 1973), catalyses reactions necessary for the conversion of hydrogen peroxide and fatty acid hydroperoxides into water and fatty acid alcohols using reduced glutathione. These processes protect cell membranes against oxidative damage (Lin and Shiau, 2005).

Studies on Se requirements led to quantification of this element in a number of fish species, e.g., rainbow trout (Hilton et al., 1980), channel catfish (Gatlin and Wilson, 1984) and juvenile grouper (Lin and Shiau, 2005). An increase in the fat content of the diet may lead to a higher level of non-enzymatic antioxidants, thereby increase the Se requirement. Moreover, most previous experiments in dietary Se requirements for rainbow trout and Atlantic salmon were conducted using mineral Se (Hilton et al., 1980; Bell et al., 1986, 1987; Talas et al., 2008). This has been reported to have lower bioavailability and trophic transfer properties compared with organic Se (selenomethionine) (Lorentzen et al., 1994; Wang and Lovell, 1997; Fan et al., 2002).

Therefore, the main objective of the present study was to study the impact of dietary fat on the organic Se requirement in growing rainbow trout and also to investigate the effect of Se on the oxidation level in fish.

\section{Material and methods}

This experiment was conducted according to the rules and regulations approved by the Ethics Committee Judging Animal Experiments of the Iranian Veterinary Medical Association.

\section{Experimental diets}

Six experimental diets were formulated according to a $3 \times 2$ factorial design. Diet formulation and proximate composition analyses are shown in Table 1. There were two variables in the current experiment. The first variable was organic Se (selenomethionine, Sigma Chemical) that was used as the Se source and supplemented at $0.1,0.15$ and $0.2 \mathrm{mg}$ per $\mathrm{kg}$ diet. The second variable was the inclusion level of fat in the
Table 1. Feed ingredients and nutrient composition of six experimental diets ( $\mathrm{g} \cdot \mathrm{kg}^{-1}$ or $\mathrm{kJ} \cdot \mathrm{g}^{-1}$ wet weight). Each value is the mean of three sub-samples

\begin{tabular}{|c|c|c|c|c|c|c|}
\hline \multirow{3}{*}{ Indices } & \multicolumn{6}{|c|}{ Se levels, $\mathrm{mg} \cdot \mathrm{kg}^{-1}$} \\
\hline & \multicolumn{3}{|c|}{ low-fat diet, $15 \%$} & \multicolumn{3}{|c|}{ high-fat diet, $30 \%$} \\
\hline & 0.1 & 0.15 & 0.2 & 0.1 & 0.15 & 0.2 \\
\hline \multicolumn{7}{|l|}{ Ingredients } \\
\hline wheat meal & 100 & 100 & 100 & 40 & 40 & 40 \\
\hline wheat gluten & 100 & 100 & 100 & 140 & 140 & 140 \\
\hline maize meal & 80 & 80 & 80 & 0 & 0 & 0 \\
\hline fish oil & 100 & 100 & 100 & 250 & 250 & 250 \\
\hline fish meal & 415 & 415 & 415 & 415 & 415 & 415 \\
\hline soyabean meal & 150 & 150 & 150 & 100 & 100 & 100 \\
\hline mineral premix ${ }^{1}$ & 10 & 10 & 10 & 10 & 10 & 10 \\
\hline vitamin premix² & 15 & 15 & 15 & 15 & 15 & 15 \\
\hline binder & 20 & 20 & 20 & 20 & 20 & 20 \\
\hline monocalcium phosphate & 10 & 10 & 10 & 10 & 10 & 10 \\
\hline \multicolumn{7}{|c|}{ Nutrient composition of the experimental diets } \\
\hline dry matter & 926.0 & 446.5 & 149.2 & 117.4 & 212.6 & 616.53 \\
\hline crude protein & 925.1 & 448.8 & 150.3 & 117.7 & 208.2 & 216.53 \\
\hline crude fat & 929.3 & 448.2 & 151.0 & 117.8 & 211.7 & 716.53 \\
\hline ash & 932.7 & 431.8 & 304.6 & 109.0 & 86.1 & 20.74 \\
\hline carbohydrates & 938.5 & 430.1 & 306.8 & 109.7 & 90.8 & 20.74 \\
\hline gross energy, $\mathrm{MJ} \cdot \mathrm{kg}^{-1}$ & 936.9 & 432.0 & 306.1 & 109.9 & 88.9 & 20.74 \\
\hline
\end{tabular}

1mg: Fe (as FeSO $47 \mathrm{H}_{2} \mathrm{O}$ ) 6000, $\mathrm{Zn}$ (as $\mathrm{ZnSO}_{4} \cdot 7 \mathrm{H}_{2} \mathrm{O}$ ) 12000, I (as $\left.\mathrm{KIO}_{3}\right) 1500, \mathrm{NaCl} 240000$, carrier (wheat middling or starch); ${ }^{2}$ vitamin

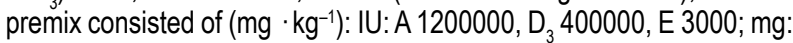
$\mathrm{K}_{3} 1200, \mathrm{C} 5400, \mathrm{H}_{2} 200, \mathrm{~B}_{1} 200, \mathrm{~B}_{2} 3360, \mathrm{~B}_{3} 7200, \mathrm{~B}_{5} 9000, \mathrm{~B}_{6} 2400$, $B_{9} 600, B_{12} 4 ;{ }^{3}$ selenomethionine, Sigma Chemical

diets: low-fat (15\%) and high-fat (30\%). This led to the production of six experimental diets with different levels of fat and organic Se. All ingredients were finely ground, mixed and pelleted. A pelleting press (Pars-Khazar, Tehran, Iran) with $2 \mathrm{~mm}$ diameter die was used for producing the diets. Thereafter, pellets were cooled, dried in an air dryer with ambient air and stored at $-20^{\circ} \mathrm{C}$ until use. Fish on all dietary treatments received almost the same amount of crude protein but different amounts of crude fat.

Although fish meal is known as a natural source of Se, the digestibility of Se in dietary fish meal is low in comparison with selenomethionine $(46.6 \%$ vs $91.6 \%$; Bell and Cowey, 1989). Therefore, the actual fish meal Se bioavailability was not so considerable as to have a significant effect on the results. Moreover, to avoid the impact of the Se present in the mineral premix, the mineral supplement was composed of essential elements without Se based on the mineral premix specification for salmonid diets (Hardy, 2002).

\section{Experimental system and animals}

In this study, rainbow trout with an initial body weight of $6.99 \pm 0.9 \mathrm{~g}$ were used. The fish were obtained from a nearby rainbow trout farm (Joya farm, Sari, Iran). They were kept in 18 fibreglass tanks with 
a capacity of 3001 each at a stocking density of 25 fish per tank. The initial and final stocking densities were 0.58 and $2.08 \mathrm{~kg} \cdot \mathrm{m}^{-3}$, respectively. The photoperiod regime during the experiment was $12 \mathrm{~h}$ light and 12 h dark.

Water quality parameters were checked three times per week after the first feeding. The measured parameters were: temperature, conductivity, $\mathrm{pH}$, oxygen and $\mathrm{NH}_{4}^{+}$contents. The oxygen concentration was measured in a randomly selected tank by a digital oxygen detector and always remained around $8 \mathrm{mg} \cdot 1^{-1}$ ( $80 \%$ saturation). The ammonia concentration was checked in the outflow of a randomly selected tank and was always below $0.1 \mathrm{mg} \cdot \mathrm{1}^{-1}$. The water $\mathrm{pH}$ ranged between 7.5 to 8 and the water temperature was kept at $14 \pm 0.5^{\circ} \mathrm{C}$ during the experiment.

\section{Experimental procedure}

The research lasted for eight weeks and comprised one week of adaptation to the facility and a seven-week experimental period. At the start of the experiment, fish were randomly allocated to one of 18 tanks. The six experimental diets were randomly assigned to each of 18 tanks, with three replicates per diet. Fish were fed to apparent satiation, three times per day by hand at $09.00,13.00$ and $18.00 \mathrm{hrs}$.

At the end of the experiment, all fish were weighed individually. Afterward, five fish were randomly selected from each tank and sacrificed using overdosed clove essence solution for analysis of body part composition. The muscle was selected from skin-free dorsal muscle between the operculum and dorsal fin of the fish. The proximate composition and rate of oxidation of muscle were analysed. The whole viscera were removed and livers were separated from the viscera. Se concentrations of the livers and muscles were also measured.

On the final day of the experiment, blood samples were also taken for plasma glutathione peroxidase activity analysis. From each tank, three fish were randomly selected and immediately put in anaesthesia (clove essence solution). Around one millilitre of blood was collected from the caudal vein from all of the selected fish by hypodermic syringe (containing $3 \mathrm{mg} \mathrm{Na}{ }_{2}$ EDTA as an anticoagulant). The collected samples were placed in cooled $1.5 \mathrm{ml}$ plastic tubes until analysis.

\section{Chemical analysis}

Feed samples were collected at regular intervals (twice a week) during the experimental period and ground using a $1 \mathrm{~mm}$ screen before analysis. Muscle samples collected from each experimental tank were ground and pooled. All chemical analy- ses were done in triplicate. Feed and muscle were analysed for dry matter by drying samples for $4 \mathrm{~h}$ at $103^{\circ} \mathrm{C}$ until constant weight (ISO, 1983). Ash content was determined by incineration in a muffle furnace for $4 \mathrm{~h}$ at $550^{\circ} \mathrm{C}$ (ISO, 1978). Crude protein (N $x$ 6.25) was measured by the Kjeldahl method after acid digestion, according to ISO (1979). Lipid was extracted by petroleum ether in a Soxhlet apparatus. Energy content was measured by direct combustion in an adiabatic bomb calorimeter (IKA-C-7000, Fa. IKA- Analysen Technik, Weitersheim, Germany).

For Se measurement, fresh samples of liver and muscle were homogenized and then digested using a combination of nitric acid and perchloric acid at a ratio of four to one. Se measurement was conducted by the use of a PerkinElmer Atomic Absorption spectrophotometer equipped with a graphite furnace according to Endo et al. (2008).

For the thiobarbituric acid reactive substance (TBARS) test, $200 \mathrm{mg}$ of muscle were added to $1 \mathrm{ml} 1$-butanol and the solution was mixed. TBARS measurement was done on the mixed samples based on a colorimetric method (Kirk and Sawyer, 1991).

GSH-Px activity was measured by the use of the blood samples based on the method developed by Paglia and Valentine (1967).

\section{Fish performance}

Weight gain was determined by the difference between total initial and final body weights. Feed conversion ratio (FCR) was calculated per tank from feed intake data and weight gain. Specific growth rate (SGR) was calculated from the natural logarithm of the mean final weight minus the natural logarithm of the mean initial weight and divided by the total number of experimental days expressed as a percentage per day. Protein efficiency ratio (PER) was calculated per tank from weight gain data and dietary crude protein. Protein production value (PPV) was calculated from protein gain and protein intake per tank. The calculations were based on the wet weight of the diet.

\section{Statistical analysis}

Data are presented as means of each treatment with standard deviation. The percentage data were verified for normality after transformation (ASIN). All data were analysed by 2-way ANOVA for the effect of Se concentrations $\left(0.1,0.15\right.$ and $\left.0.2 \mathrm{mg} \cdot \mathrm{kg}^{-1}\right)$ and the effect of fat levels (15\% and $30 \%)$. The Student pair t-test was used to compare two lipid levels of the diets. For all statistical analyses, a tank was considered as the experimental unit. 


\section{Results}

Final weight was not influenced by either the effect of fat or Se content of the diets (Table 2). Increasing the Se content of the high-fat diets did result, however, in an increased SGR $(P<0.01)$ and lower FCR $(P<0.01)$. There was an interaction between $\mathrm{Se}$ and fat levels for growth-related parameters showing that the effect of dietary fat on growth depends on the Se content of the diets. In other words, Se supplementation $(0.15$ and $0.2 \mathrm{mg}$ $\cdot \mathrm{kg}^{-1}$ ) only improved growth parameters when fish were fed on the high-fat diets.
A high dietary inclusion level of fat did not improve $(P>0.01)$ PER, but increased PPV $(P<0.01)$. An interaction effect was present for the PER between Se and fat inclusion levels $(P<0.05$; Table 2 ) indicating that the positive effect of fat on protein efficiency depends on the Se level of the diet.

The effects of Se on GSH-px activity and oxidation rate in tissues are presented in Table 3 . In general, GSH-px activity in blood was lower on the high-fat diet. However, on this diet GSH-px activity increased as Se was increased (from 0.10 to 0.15 $\left.\mathrm{mg} \cdot \mathrm{kg}^{-1}\right)$. Increasing the dietary inclusion level of $\mathrm{Se}$ (from 0.10 to $\left.0.15 \mathrm{mg} \cdot \mathrm{kg}^{-1}\right)$ reduced $(P<0.01)$

Table 2. Growth performance in rainbow trout fed diets with different levels of fat $(\%)$ and selenium $\left(\mathrm{mg} \cdot \mathrm{kg}^{-1}\right)$ over a 7 -weeks experimental period. All values are means of three replicates (tanks)/treatment \pm standard deviation

\begin{tabular}{|c|c|c|c|c|c|c|c|c|c|}
\hline \multirow{3}{*}{ Indices } & \multicolumn{6}{|c|}{ Se levels, $\mathrm{mg} \cdot \mathrm{kg}^{-1}$} & \multirow{3}{*}{ Fat } & \multirow{3}{*}{ Se } & \multirow{3}{*}{ Fat $\times \mathrm{Se}$} \\
\hline & \multicolumn{3}{|c|}{ low-fat diet, 15\% } & \multicolumn{3}{|c|}{ high-fat diet, $30 \%$} & & & \\
\hline & 0.1 & 0.15 & 0.2 & 0.1 & 0.15 & 0.2 & & & \\
\hline Initial weight, g & $7.17 \pm 0.5$ & $7.05 \pm 0.3$ & $7.06 \pm 0.4$ & $6.97 \pm 0.7$ & $7.08 \pm 0.4$ & $6.64 \pm 0.1$ & ns & ns & ns \\
\hline Final weight, g & $25.6 \pm 1.2^{\mathrm{ab}}$ & $25.2 \pm 0.0^{\mathrm{ab}}$ & $26.1 \pm 1.8^{\mathrm{ab}}$ & $22.3 \pm 2.3^{b}$ & $27.3 \pm 0.8^{a}$ & $25.4 \pm 2.1^{a b}$ & ns & ns & $P<0.05$ \\
\hline FCR & $1.11 \pm 0.02^{\mathrm{b}}$ & $1.13 \pm 0.02^{2 \mathrm{ab}}$ & $1.06 \pm 0.04^{b}$ & $1.32 \pm 0.07^{\mathrm{a}}$ & $1.00 \pm 0.01^{b}$ & $1.08 \pm 0.08^{b}$ & $P<0.01$ & $P<0.01$ & $P<0.05$ \\
\hline SGR & $2.59 \pm 0.0$ & $2.60 \pm 0.0$ & $2.66 \pm 0.0$ & $2.37 \pm 0.0$ & $2.75 \pm 0.0$ & $2.73 \pm 0.2$ & ns & $P<0.01$ & $P<0.05$ \\
\hline PER & $2.00 \pm 0.0$ & $1.95 \pm 0.0$ & $2.10 \pm 0.1$ & $1.75 \pm 0.1$ & $2.30 \pm 0.0$ & $2.15 \pm 0.2$ & ns & $P<0.01$ & $P<0.05$ \\
\hline PPV & $0.30 \pm 0.0$ & $0.30 \pm 0.0$ & $0.31 \pm 0.0$ & $0.31 \pm 0.1$ & $0.34 \pm 0.0$ & $0.32 \pm 0.0$ & $P<0.01$ & ns & ns \\
\hline \multicolumn{10}{|c|}{ Student pair t-test for comparison of two fat levels in the diets } \\
\hline Parameters & \multicolumn{9}{|c|}{$P$-value } \\
\hline initial weight, $g$ & \multicolumn{9}{|l|}{0.173} \\
\hline final weight, $g$ & \multicolumn{9}{|l|}{0.480} \\
\hline FCR & \multicolumn{9}{|l|}{0.005} \\
\hline SGR & \multicolumn{9}{|l|}{0.421} \\
\hline PER & \multicolumn{9}{|l|}{0.521} \\
\hline PPV & \multicolumn{9}{|l|}{0.082} \\
\hline
\end{tabular}

Table 3. Glutathione peroxidase activity, oxidation rate of tissue and accumulation of selenium in the liver and muscle tissue of rainbow trout fed diets with different levels of fat and selenium over a 7-week experimental period. All values are means of three replicates (tanks)/treatment \pm standard deviation

\begin{tabular}{|c|c|c|c|c|c|c|}
\hline \multirow{2}{*}{ Indices } & \multicolumn{3}{|c|}{ Selenium level, $\mathrm{mg} \cdot \mathrm{kg}^{-1}$} & \multirow{2}{*}{ Fat } & \multirow{2}{*}{ Se } & \multirow{2}{*}{ Fat $\times \mathrm{Se}$} \\
\hline & 0.1 & 0.15 & 0.2 & & & \\
\hline \multicolumn{4}{|c|}{ Glutathione peroxidase (GSH-px), $\mathrm{U} \cdot \mathrm{ml}^{-1}$ whole blood } & $P<0.01$ & $P<0.01$ & $P<0.01$ \\
\hline fat $15 \%$ & $21.9 \pm 1.6^{\mathrm{a}}$ & $20.3 \pm 0.6^{\mathrm{a}}$ & $21.7 \pm 1.9^{\mathrm{a}}$ & & & \\
\hline fat $30 \%$ & $13.3 \pm 0.5^{b}$ & $19.7 \pm 0.5^{\mathrm{a}}$ & $19.5 \pm 0.7^{\mathrm{a}}$ & & & \\
\hline \multicolumn{4}{|c|}{ Thiobarbituric acid test (TBARS), $\mathrm{mg} \cdot \mathrm{kg}^{-1}$} & $P<0.01$ & $P<0.01$ & $P<0.01$ \\
\hline fat $15 \%$ & $0.01 \pm 0.005^{c}$ & $0.008 \pm 0.0003^{c}$ & $0.01 \pm 0.007^{c}$ & & & \\
\hline fat $30 \%$ & $0.07 \pm 0.005^{\mathrm{a}}$ & $0.02 \pm 0.0005^{b}$ & $0.03 \pm 0.003^{b}$ & & & \\
\hline \multicolumn{4}{|c|}{ Selenium accumulation amount in muscle tissue, $\mathrm{mg} \cdot \mathrm{g}^{-1}$} & $P<0.05$ & ns & ns \\
\hline fat $15 \%$ & $0.254 \pm 0.01^{\mathrm{a}}$ & $0.272 \pm 0.04^{a}$ & $0.281 \pm 0.04^{a}$ & & & \\
\hline fat $30 \%$ & $0.218 \pm 0.01^{a}$ & $0.228 \pm 0.006^{a}$ & $0.238 \pm 0.01^{\mathrm{a}}$ & & & \\
\hline \multicolumn{4}{|c|}{ Selenium accumulation amount in liver tissue, $\mathrm{mg} \cdot \mathrm{g}^{-1}$} & $P<0.01$ & $P<0.05$ & ns \\
\hline fat $15 \%$ & $0.764 \pm 0.005^{\mathrm{a}}$ & $0.809 \pm 0.02^{\mathrm{ab}}$ & $0.858 \pm 0.04^{a}$ & & & \\
\hline fat $30 \%$ & $0.489 \pm 0.1^{c}$ & $0.637 \pm 0.02 b^{c}$ & $0.757 \pm 0.04^{\mathrm{ab}}$ & & & \\
\hline \multicolumn{7}{|c|}{ Student pair t-test for comparison of two fat levels in the diets } \\
\hline \multirow{5}{*}{\multicolumn{2}{|c|}{$\begin{array}{l}\text { Parameters } \\
\text { glutathione peroxidase } \\
\text { thiobarbituric acid } \\
\text { selenium in muscle } \\
\text { selenium in liver }\end{array}$}} & $P$-value & & & & \\
\hline & & 0.009 & & & & \\
\hline & & 0.001 & & & & \\
\hline & & 0.046 & & & & \\
\hline & & 0.008 & & & & \\
\hline
\end{tabular}

a,b means with different superscipts within a row are significantly different at $P \leq 0.05$; ns - not significant 
Table 4. Proximate composition of rainbow trout muscle fed diets with different levels of fat and selenium over a 7-week experimental period. All values are means of three replicates (tanks)/treatment \pm standard deviation

\begin{tabular}{|c|c|c|c|c|c|c|c|c|c|}
\hline \multirow{3}{*}{ Indices } & \multicolumn{6}{|c|}{ Selenium levels, $\mathrm{mg} \cdot \mathrm{kg}^{-1}$} & \multirow{3}{*}{ Fat } & \multirow{3}{*}{ Se } & \multirow{3}{*}{ Fat $\times \mathrm{Se}$} \\
\hline & \multicolumn{3}{|c|}{ low-fat diet, $15 \%$} & \multicolumn{3}{|c|}{ high-fat diet, $30 \%$} & & & \\
\hline & 0.1 & 0.15 & 0.2 & 0.1 & 0.15 & 0.2 & & & \\
\hline Crude protein, $\%$ & $19.1 \pm 1.2$ & $20.0 \pm 2.1$ & $19.6 \pm 1.8$ & $18.9 \pm 2.2$ & $20.7 \pm 1.9$ & $19.1 \pm 2.1$ & ns & ns & ns \\
\hline Crude lipid, \% & $5.7 \pm 0.9$ & $5.4 \pm 0.8$ & $6.4 \pm 0.2$ & $6.5 \pm 0.7$ & $8.8 \pm 0.3$ & $8.3 \pm 0.4$ & $S$ & ns & ns \\
\hline Ash, $\%$ & $1.9 \pm 0.02$ & $1.9 \pm 0.03$ & $1.8 \pm 0.02$ & $1.7 \pm 0.04$ & $1.8 \pm 0.05$ & $1.7 \pm 0.02$ & ns & ns & ns \\
\hline Moisture, \% & $72.3 \pm 3.1$ & $71.5 \pm 2.8$ & $72.1 \pm 2.5$ & $72.2 \pm 3.4$ & $72.1 \pm 3.4$ & $72.6 \pm 2.6$ & ns & ns & ns \\
\hline \multicolumn{10}{|c|}{ Student pair t-test for comparison of two fat levels in the diets } \\
\hline Parameters & \multicolumn{9}{|c|}{$\mathrm{p}$-value } \\
\hline crude protein & \multicolumn{9}{|l|}{0.395} \\
\hline crude lipid & \multicolumn{9}{|l|}{0.002} \\
\hline ash & \multicolumn{9}{|l|}{0.441} \\
\hline moisture & \multicolumn{9}{|l|}{0.384} \\
\hline
\end{tabular}

the measurement based on the wet weight of the samples; ns - not significant, $\mathrm{S}$ - significant

TBARS. This trend was, however, more obvious for the high-fat diet that for the low-fat one.

An increase in the Se level of the diets did not affect $(P>0.05)$ the Se content of the muscle, but Se accumulation in the liver was higher $(P<0.05)$ on the high-Se diet (Table 3). Se accumulation was always lower in both liver and muscle on the high-fat diets than on the low-fat ones. There was no interaction between fat and Se levels for Se accumulation in either liver or muscle.

Body composition was not affected by addition of Se. The high-fat diet did, however, lead to a larger fat content of the fish muscle $(P<0.05$; Table 4$)$.

\section{Discussion}

The present study showed that the growth-related parameters were not improved by the fat content of the diets, but PPV improved on the high-fat diets. This is in contrast to a number of previous studies on different species, including that by Lee and Kim (2001) in masu salmon, Chan et al. (2002) in coho salmon, Meyer and Fracalossi (2004) in Rhamdia quelen, Wang et al. (2006) in cuneate drum, and Salhi et al. (2004) in black catfish. Those authors concluded that increasing the dietary energy level through a high-fat diet increases growth and PER by improving the protein-sparing effect. It appears that the rainbow trout energy requirement is met by a diet containing $16.5 \mathrm{~kJ} \cdot \mathrm{g}^{-1}$ energy (with $43 \%$ protein) and extra energy does not lead to further growth.

The similar growth rates of the fish on both the high- and low-fat diets might also have been caused by the increased oxidation level induced by the high-fat diets (Pickering et al., 1991; Montero et al., 1999; Trenzado et al., 2006). Higher levels of TBARS on the high-fat diets confirm the idea that there is a direct relationship between fat oxidation in tissue and fat content of the diets which, in turn, may have a negative impact on rainbow trout growth. Nonetheless, the interaction effect between fat and Se suggests that addition of Se reduced the TBARS concentration only on the high-fat diet. This may be related to the role of Se in the activation of GSH-px and reducing the oxidative damage of the cell membrane (Lin and Shiau, 2005).

The reduced oxidation rate induced by Se supplementation up to $0.15 \mathrm{mg} \cdot \mathrm{kg}^{-1}$ improved feed efficiency on high-fat diets, but the positive effect declined with further increase of Se. This may be related to toxic effect of this mineral at the higher supplementation level (Hilton et al., 2009), which can limit the role of Se as an antioxidant in fish nutrition. Hilton et al. (1980) also added that Se was toxic at concentrations only slightly greater than nutritional requirements.

The positive effects of $\mathrm{Se}$ inclusion (up to $1.5 \mathrm{mg} \cdot \mathrm{kg}^{-1}$ ) on SGR and PER on high-fat diets are apparently related to the promotion of antioxidant activity in rainbow trout. This condition is associated with increasing GSH-px activity and decreasing the TBARS concentration in fish tissue (Table 3). A positive relationship between the Se content of the diets and GSH-px activity was also reported by Bell et al. (1987) in Salmo salar, Lin and Shiau (2005) in Epinephelusma labaricus, and Zhou et al. (2009) in Carassius auratus gibelio. Increasing the Se level of the diets led to higher deposition of Se in the liver. This finding is similar to that of Wang et al. (2007) and Kucukbay et al. (2009) who observed increased liver Se accumulation with higher Se supplementation. In our experiment, however, the measured Se accumulation in both liver and muscle were lower in fish fed the high-fat diet. This may be because the free radical production caused by oxidative stress (Halliwell and Gutteridge, 1989) leads 
to larger production of GSH-px (Chaiyapechara et al., 2003; Sahin and Kucuk, 2003; Kucukbay et al., 2009). Se as an integral part of GSH-px (Rotruck et al., 1973), takes part in the cellular defense against oxidative damage of fat peroxides (Watanabe et al., 1997). This may explain the lower accumulation of Se in liver and muscle on high-fat diets.

The muscle fat content was influenced by the fat level of the diets (Table 4). This may suggest that a high-fat diet does not necessarily improve PER in rainbow trout and may lead to fat deposition in the fish body (Hemre and Sandnes, 1999). Therefore, more $\mathrm{Se}$ is required to reduce the stress induced by fat oxidation in muscle when fish feed on a high-fat diet.

In conclusion, addition of $\mathrm{Se}$ as selenomethionine is essential for rainbow trout, especially when a high-fat diet is applied. A reduction in oxidation level was observed by inclusion of Se in the diets, which is associated with a higher activity of GSH-px. More Se is necessary to reduce the oxidative level of rainbow trout fed on a high-fat diet. Based on these results, we can suggest an amount of $0.15 \mathrm{mg} \cdot \mathrm{kg}^{-1} \mathrm{Se}$ for a diet containing $30 \%$ fat.

\section{Acknowledgements}

The first author of the article would like to thank the lab technician of the Department of Fishery at TMU for kind assistance during the sampling procedure. Special thanks goes to Eng. Sadegh Karimzadeh for his support and proving materials throughout planning and execution of the study.

\section{References}

Bell J.G., Cowey C.B., 1989. Digestibility and bioavailability of dietary selenium from fish meal, selenite, selenomethionine and selenocysteine in Atlantic salmon parr (Salmo salar). Aquaculture 81, 61-68

Bell J.G., Cowey C.B., Adron J.W., Pirie B.J.S., 1987. Some effects of selenium deficiency on enzyme activities and indices of tissue peroxidation in Atlantic salmon parr (Salmo salar). Aquaculture 65, 43-54

Bell J.G., Pirie B.J.S., Adron J.W., Cowey C.B., 1986. Some effects of selenium deficiency on glutathione Peroxidase (EC1.11.19) activity and tissue pathology in rainbow trout (Salmo gairdneri). Brit. J. Nutr. 55, 305-311

Bureau D.P., Hua K., 2010. Towards effective nutritional management ofwaste outputs in aquaculture, with particular reference to salmonid aquaculture operations. Aquac. Res. 41, 777-792

Chaiyapechara S., Castenb M.T., Hardyb R.W., Dong F.M., 2003. Fish performance, fillet characteristics, and health assessment index of rainbow trout (Oncorhynchus mykiss) fed diets containing adequate and high concentrations of lipid and vitamin $\mathrm{E}$. Aquaculture 219, 715-738

Chan J.C.K., Manu J., Skura B.J., Rowshandeli M., Rowshandeli N., Higgs D.A., 2002. Effects of feeding diets containing various dietary protein and lipid ratios on the growth performance and pigmentation of post-juvenile Coho salmon Oncorhynchus kisutch reared in sea water. Aquac. Res. 33, 1137-1156

Cheung C.C.C., Siu W.H.L., Richardson B.J., De Luca-Abbott S.B., Lam P.K.S., 2004. Antioxidant responses to benzo[a]pyreeneandArochlor 1254 exposure in the green-lipped mussel, Perna viridis. Environ. Pollut. 128, 393-403

Cho C.Y., Bureau D.P., 2001. A review of diet formulation strategies andfeeding systems to reduce excretory and feed wastes in aquaculture. Aquac. Res. 32, 349-360

Dumas A., de Lange C.F.M., France J., Dominique P., Bureau D.P., 2007. Quantitative description of body composition and rates of nutrient deposition in rainbow trout (Oncorhynchus mykiss). Aquaculture 273, 165-181

Endo T., Hisamichi Y., Kimura O., Haraguchi K., Baker C.S., 2008. Contamination levels of mercury and cadmium in melonheadwhales (Peponoce falaelectra) from a mass stranding on tapaneas coast. J. Environ. Pollut. 135, 163-170

Fan T.W.M., Teh S.J., Hinton D.E., Higashi R.M., 2002. Selenium biotransformations into proteinaceous forms by food web organisms of selenium-laden drainage waters in California. Aquat. Toxicol. 57, 65-84

Gatlin D.M., Wilson R.P., 1984. Dietary selenium requirement of fingerling channel catfish. J. Nutr. 114, 627-633

Halliwell B.E., Gutteridge J.M.C., 1989. Lipid peroxidation: a radical chainreaction. In: Free Radicals in Biology and Medicine. $2^{\text {nd }}$ Edition. Oxford University Press, New York, NY, pp. 188-218

Hardy R.W., 2002. Rainbow trout, Oncorhynchus mykiss. In: C. Lim, C.D. Webster (Editors). Nutrient Requirements and Feeding of Aquaculture Fish. CABI Publication, Wallingford (UK), pp. 192-193

Hemre G.I., Sandnes K., 1999. Effect of dietary lipid level on muscle composition in Atlantic salmon, Salmo salar,. Aquacult. Nutr. $5,9-16$

Hilton J.W., Hodson P.V., Slinger S.J., 1980. The requirements and toxicity of selenium in rainbow trout (Salmo gairdneri). J. Nutr. 110, 2527-2535

Hilton J.W., Hodson P.V., Slinger S.J., 2009. The requirements and toxicity of selenium in rainbow trout (Salmo gairdneri). J. Nutr. $110,2527-2535$

Hung S.S.O., Storebakken T., Cui Y.,Tian L., Einen O., 1997. High energy diets for white sturgeon (Acipenser transmontanus, Richardson). Aquacult. Nutr. 3, 281-286

ISO, 1978. Animal Feeding Stuffs. Determination of Crude Ash. ISO 5984. International Organization for Standardization

ISO, 1979. Animal Feeding Stuffs. Determination of Nitrogen Content and Calculation of Crude Protein Content. ISO 5983. International Organizationfor Standardization

ISO, 1983. Animal Feeding Stuffs. Determination of Moisture Content. ISO 6496. International Organization for Standardization

Jobling M., Koskela J., Savolainen R., 1998. Influence of dietary fat level and increased adiposity on growth and fat deposition in rainbow trout, Oncorhynchus mykiss (Walbaum). Aquac. Res. 29, 601-607

Kirk R., Sawyer R., 1991. Pearson's Composition and Analysis of Foods. $9^{\text {th }}$ Edition. Longman Scientific and Technical, pp. 642-643

Kucukbay F.Z., Yazlak H., Karaca I., Sahin N., Tuzcu M., Cakmak M.N., Sahin K., 2009. The effects of dietary organic or inorganic seleniumin rainbow trout (Oncorhynchus mykiss) under crowding conditions. Aquacult. Nutr. 15, 569-576

Lee S.M., Kim K.D., 2001. Effects of dietary protein and energy levels on the growth, protein utilization and body composition of juvenile Masu salmon (Oncorhynchus masou Brevoort). Aquac. Res. 32, 39-45

Lin Y.H., Shiau S.Y., 2005. Dietary selenium requirements of juvenile grouper, Epinephelus malabaricus. Aquaculture 250, 356-363 
Lorentzen M., Maage A., Julshamn K., 1994. Effects of dietary selenite or selenomethionine on tissue selenium levels of Atlantic salmon (Salmo salar). Aquaculture 121, 359-367

Meyer G., Fracalossi D.M., 2004. Protein requirement of jundia fingerlings, Rhamdiaquelen, at two dietary energy concentrations. Aquaculture $240,331-343$

Montero D., Izquierdo M.S., Tort L., Robaina L., Vergara J.M., 1999. High stocking density produces crowding stress altering somephysiological and biochemical parameters in gilthead seabream, Sparusaurata, juveniles. Fish Physiol. Biochem. $20,53-60$

Morais S., Koven W., Rønnestad I., Dinis M.T., Conceicao L.E.C., 2005. Dietary protein:lipid ratio and lipid nature affects fatty acid absorption and metabolism in a teleost larva. Brit. J. Nutr. 93, 813-820

Mruk D.D., Silvestrini B., Meng-yun M.O., Cheng Y.C., 2002. Antioxidant superoxide dismutase a review: its function, regulation in the testis, and rolein male fertility. Contraception 65, 305-311

Nogueira C.W., Quinhones E.B., Jung E.A.C., Zeni G., Rocha J.B.T., 2003. Anti-inflammatory and antinociceptive activity of biphenyldiselenide. Inflamm. Research 52, 56-63

Paglia D.E., Valentine W.N., 1967. Studies on the quantitative and qualitative characterization of erythrocyte glutathione peroxidase. Lab. Clin. Med. 70, 158-169

Pickering A.D., Pottinger T.G., Sumpter J.P., Carragher J.F., Le Bail P.Y., 1991. Effects of acute and chronic stress on the levels of circulating growth hormone in the rainbow trout, Oncorhynchus mykiss. Gen. Comp. Endocrinol. 83, 86-93

Rasmussen R.S., 2001. Quality of farmed salmonids with emphasis on proximate composition, yield, and sensory characteristics. Aquac. Res. 32, 767-786

Rotruck J.T., Pope A.L., Ganther H.E., 1973. Selenium: biochemical roleas a component of glutathione peroxidase. Science 179 , $585-590$

Ruohonen K., Kettunen J., King J., 2001. Experimental design in feeding experiments. In: D. Houlihan, T. Boujard, M. Jobling (Editors). Food Intake in Fish. Blackwell Publishing, Oxford, pp. 88-107

Sahin K., Kucuk O., 2003. Heat stress and dietary vitamin supplementation of poultry diets. Nutr. Abst. Rev. Ser. B 73, 41-50

Sakai T., Murata H., Endo M., Shimomura T., Yamauchi K., Ito T., Yamaguchi T., Nakajima H., Fuku-dome M., 1998. Severe oxidative stress is thought to be a principle cause of jaundice of yellow tail Seriolaquinqu eradiata. Aquaculture 160, 205-214

Salhi M., Bessonart Chediak M.G., Bellagamba Carnevia M.D., 2004. Growth, feed utilization and body composition of black catfish,
Rhamdia quelen, fry fed diets containing different protein and energy levels. Aquaculture 231, 435-444

Sargent J.R., Tocher D.R., Bell J.G., 2002. The lipids. In: J.E. Halver, R.W. Hardy (Editors), Fish Nutrition. $3^{\text {rd }}$ Edition. Academic Press, San Diego, pp. 181-258

Steffens W., Rennert B., Wirth M., Krüger R., 1999. Effect of two lipid levels on growth, feed utilization, body composition and some biochemical parameters of rainbow trout, Oncorhynchus mykiss (Walbaum 1792). J. Appl. Ichthyol. 15, 159-164

Talas Z.S., Orun I., Ozdemir I., Erdogan K., Alkan A., Yılmaz I., 2008. Antioxidative role of selenium against the toxic effect of heavy metals $\left(\mathrm{Cd}^{+2}, \mathrm{Cr}^{+3}\right)$ on liver of rainbow trout (Oncorhynchus mykiss Walbaum 1792). Fish Physiol. Biochem. 34, 217-222

Trenzado C.E., Morales A.E., Higuera M., 2006. Physiological effects of crowding in rainbow trout, Oncorhynchus mykiss, selected for low and high stress responsiveness. Aquaculture 258, 583-593

Turchini G.M., Torstensen B.E., Ng W.-K., 2009. Fish oil replacement in finfish nutrition. Rev. Aquaculture 1, 10-57

Wang C., Lovell R.T., 1997. Organic selenium sources, selenomethionine and selenoyeast, have higher bioavailability than an inorganic selenium source, sodium selenite, in diets for channel catfish (Zctalurus punctatus). Aquaculture 152, 223-234

Wang H.L., Zhang J.S., Yu H.Q., 2007. Elemental selenium at nano size possesses lower toxicity without compromising the fundamental effect on selenoenzymes: comparison with selenomethionine in mice. Free Radical Biol. Med. 42, 1524-1533

Wang Y., Guo J., Li K., Bureau D.P., 2006. Effects of dietary protein and energy levels on growth, feed utilization and body composition of cuneate drum (Nibeamii chthioides). Aquaculture 252, 421- 428

Watanabe T., Kiron V., Satoh S., 1997. Trace minerals in fish nutrition. Aquaculture 151, 185-207

Wiseman S., Thomas J.K., Higley E., Hursky O., Pietrock M., Raine J.C., Giesy P.J., Janz D.M., Hecker M., 2011. Chronic exposure to dietary selenomethionine increases gonadal steroidogenesis in female rainbow trout. Aquac. Toxicol. 105, 218-226

Yamamoto T., Shima T., Furuita H. et al., 2002. Influence of dietary fat leveland whole-body adiposity on voluntary energy intake by juvenile rainbow trout Oncorhynchus mykiss (Walbaum) under self-feeding conditions. Aquac. Res. 33, 715-723

Zhou X., Wang Y., Gu Q., Li W., 2009. Effects of different dietaryselenium sources (selenium nanoparticle and selenomethionine) on growth performance, muscle composition and glutathione peroxidase enzyme activity of crucian carp (Carassius auratus gibelio). Aquaculture 291, 78-81 